\title{
Review | Out of Order: A Photographic Celebration of the Free Party Scene
}

\author{
Molly Macindoe \\ Bristol: Tangent Books, 2011 \\ ISBN: 9781906477431
}

\author{
Hillegonda C Rietveld \\ London South Bank University \\ rietvehc@lsbu.ac.uk
}

Molly Macindoe offers a 10-year photographic record of participation in the socalled free party scene in the various countries she visited during that period, from the UK and the Netherlands to the Czech Republic. In this context, the notion of freedom is found in a mostly unlicensed environment where electronic dance music - especially techno - dominates, amplified on large mobile sound systems. Such events take place in temporarily occupied spaces, including abandoned industrial buildings and open-air settings off the beaten track, selected to evade surveillance, from police and other official bodies.

The principle of evasion draws back to the late 1980s in the UK, when acid house and rave parties started to mushroom outside of strictly regulated clubs and festival sites. Between 1989 and 1993, sensationalist newspaper reports gave cause to a moral panic, which in the UK even resulted in an amendment to its Criminal Justice Act, in which both travellers and rave parties were specifically legislated against. While aspects of this dance culture returned to the dance club environment, its politicized party offshoot spread across Europe and elsewhere in the form of teknivals and squat parties from the 1990s onwards.

Free party dance events usually take place in the dark, thereby adding to the evasiveness of the scene, especially from visual surveillance. During long nights of dancing, the effect is of losing one's individualized self, instead emphasizing the communally shared sonic aspects of the experience. In this context, the boundaries between fans and music makers can blur. And, indeed, the 
photographic record here shows how participation is crucial to the events, as the spectacle of pop entertainment is denied in this manner.

Such lack of desire to be seen adds a particular challenge to photographing the participants. People who dance in the dark prefer not to be photographed, avoiding the "mastering gaze" in a temporary moment of escape (Rietveld 2013). As participants they are not passive but dynamic subjects who move to the music and refuse to be looked at, to be objectified. Indeed, some dance clubs forbid photography, confiscating cameras and placing a sticker on mobile phone lenses. The burden of photography is the exposition of its subjects, and dancers prefer to stay in the dark rather than to "hide in the light" (Hebdige 1988).

Aware of the ethical issues, Macindoe shared the images with her subjects on the next dance occasion, and would print their favorites for their pleasure, so they also got something from the process. She shows DJs of all genders being busy with their music equipment, participants in animated discussion, and familiarity with the photographer is demonstrated by an air of playfulness, even in times of hungover recovery. Macindoe's photographic record is special, therefore, as her images are populated by people (mostly friends and familiar "faces") who seem at ease with a photographic gaze that looks from within the scene. Here, the boundaries between participation and observation blur. And this is one of the great achievements of this collection.

Even more striking, however, is that many of the photographs are taken in natural light, after the party is over rather than at the peak of the night. As a result, there is less emphasis on dancing than on people interacting with each other in the debris of the aftermath, both in terms of human exhaustion and the striking amounts of rubbish littering the various party floors. Combined with some of the post-industrial settings, the visual documentation can appear bleak, even though for scene participants it conjures memories of warmth, friendship, togetherness and fun. The collection works as a type of ethnographic record that is both personal and subjective. As a visual record of scene that is about taking part dynamically in an embodied feeling where sound overwhelms the senses, the photographic medium is taken to its own boundaries, as the still image denies the outside viewer exactly that experience. Could a still image ever convey this dynamic cultural form, form, in which sound is the dominant element, beyond triggering memory?

\section{References}

Hebdige, D. 1988. Hiding in the Light: On Images and Things. London and New York: Comedia/Routledge.

Rietveld, H. C. 2013. "Journey to the Light? Immersion, Spectacle and Mediation". In B. A. Attias, A. Gavanas and H. C. Rietveld Eds. DI Culture in the Mix: Power, Technology, and Social Change in Electronic Dance Music. New York and London: Bloomsbury Academic: 79-102. 